\title{
Interconnected Experiences: Embodying Feminist Research with Social Movements
}

\author{
Daniela Flores Golfin, Tamara Rusansky, \\ and Fleur Zantvoort
}

\section{INTRODUCTION}

This chapter is the result of a journey of three feminist researchers threading their way through academia and feminist socio-ecological struggles. While we come from three different countries and backgrounds, our own histories converge in The Hague, The Netherlands during our MA in Development Studies at the International Institute of Social Studies (ISS) in 2018-2019. We were part of a common friend group where, because of our interests and research topics, we would often find ourselves

D. Flores Golfín

San Jose, Costa Rica

e-mail: info@danielaflorespsicologia.com

T. Rusansky $(\bowtie)$

Florianópolis, Brasil

F. Zantvoort

Utrecht, The Netherlands

(C) The Author(s) 2022

W. Harcourt et al. (eds.), Feminist Methodologies,

Gender, Development and Social Change,

https://doi.org/10.1007/978-3-030-82654-3_10 
asking each other questions related to our research, sharing material and giving each other suggestions. Writing this chapter has allowed us to reflect on the interconnectedness of our MA research experiences and the ways in which we value feminist research. We have written this chapter together, seeing it as an exciting process of thinking and working together as friends.

When we began writing we were all living in The Hague and seeing each other regularly. After the MA however, we moved to different countries, time zones and making decisions on our next steps, while facing a pandemic. We continued "meeting" each other online; mixing work and fun in our conversations. We adjusted to this new reality, worked online and most importantly, checked on each other in this difficult context. As a result, our chapter is highly informed by our knowledge of each other, our strengths and our perspectives. It gave us a welcome excuse to meet frequently in circumstances where the importance of friendship was felt by all of us.

In this chapter we take the reader through our own personal grappling, with critical feminist research and struggles for social justice, as well as of our friendship and thinking through of what it means to do research with social movements using feminist research methodologies. It explores the challenges, ethics and possibilities this entails in relation to the three movements that we have aligned ourselves within the context of our MA theses research-Extinction Rebellion in the Netherlands, the Movement of People Affected by Dams in Brazil and the Abortion Rights Movement in Costa Rica. ${ }^{1}$ The three movements span different struggles and continents, yet in our research we encountered similar methodological questions, concerns and challenges. Reflecting from these different but related experiences, we explore the role of critical feminist research and knowledge generation in contributing to these specific social struggles.

First, we explore what feminist research methodology means to us, based on feminist epistemologies as well as social movement research that understands social movements as creating other ways of knowing and being (Casas-Cortés et al., 2008; Escobar, 2016; Haraway, 1988; Harding, 1987; Icaza \& Vazquez, 2013; Motta \& Esteves, 2014). Second, we delve further into how we related to movements throughout our research. We reflect on how our methodological approaches varied

${ }^{1}$ For the original MA theses see Flores (2019), Rusansky (2019), Zantvoort (2019). 
according to our different positionalities as researchers, from actively participating in the movement, to engaging in more short-term collaborations. Finally, we reflect on the role of critical feminist research in contributing to struggles for social justice, revisiting the question: for whom is knowledge being produced, and for what purpose (Leyva \& Speed, 2008: 47)?

Tamara: My research journey with the Movement of People Affected by Dams in Brazil (Movimento dos Atingidos por Barragens-MAB), particularly with women in the movement, emerged from my fascination with one of the resistance tools they use-arpilleras, a textile art technique from Chile. The technique was adopted by women organised in the MAB as a tool to narrate their stories and make political statements. The MAB is a national social movement organising the struggle of those affected by dams in different regions in Brazil. My research examined the embodied, emotional and daily resistance of women whose lives were flooded by one hydropower dam-the Baixo Iguaçu dam in the Iguaçu River Basin (South Brazil) - and reflected on the transformative potential of arpilleras as a resistance tool. Writing this chapter is part of the path of learning and unlearning that doing research alongside a social movement allowed me to traverse. This is a process of constantly questioning myself about my engagement with the political subjects of a social movement and their resistance to a neoliberal, patriarchal, colonial and racist energy development model, and their struggle for social justice.

Daniela: My research was centred around the experiences of abortion rights activists from several collectives in San José, Costa Rica. Initially my research was an exploration of individual self-care practices and tools to improve the experience of getting involved in this type of activism, but it transformed into a research on care within the movement. The research explored the care dynamics implemented by activists to care for themselves, other collectives and women in general, as well as the struggles and obstacles they encountered when doing so. I explored these dynamics, and how the women at the forefront of this movement perceive care and self-care as a resistance tool and as a standpoint for creating new ways of relating and fighting against oppression.

Fleur: When I started my graduate research project alongside Extinction Rebellion Netherlands, I was not intending to do feminist activist research. However, I was from the start guided by a commitment to social change and making explicit the power relations inherent in knowledge generation. In addition to conducting interviews, participating in 
direct actions and organising were important in informing my research. I departed from the notion that social movements are important spaces for learning and unlearning involved in the "co-construction of becoming otherwise" of communities and subjects (Motta \& Esteves, 2014: 5). Through the lens of belonging, ${ }^{2}$ I looked to shed light on the knowledges and ways of being cultivated by the movement, and the ways in which they resist and/or reinforce dominant knowledges and subjectivities in the context of the Dutch climate movement. I discussed how an embodied, emotional understanding of the climate crisis and knowledge practices of care, vulnerability and mourning can unsettle dominant discourses of human control over "nature" and presumed innocence in relation to intertwined ecological, racialised and gendered violence.

\section{What Does Feminist Research Methodology Mean to Us?}

We see one of the main contributions of feminist approaches to research is its critical interrogation of power relations and dedication to understanding and transforming intersecting systems of oppression (Crenshaw, 1989; Philip \& Bell, 2017). Rather than referring to a particular set of methods, we understand feminist methodology as a way of relating to our research; not as detached, objective researchers practising the "god-trick of seeing everything from nowhere" (Haraway, 1988: 581), but instead understanding ourselves as entangled in the co-creation of knowledge. Self-reflexivity and making explicit the ways in which power runs through us as researchers and our research relations form an important part of our methodology. We also situate ourselves within a history of feminist theories and we make sense of our "data" using feminist political ecology as well as decolonial and postcolonial feminisms.

Throughout our research, we sought to build reciprocal and caring relations with the people involved in our inquiries. We all, to a certain extent, sought to blur the boundaries between the subjects and objects of research (Casas-Cortés et al., 2008). Within the context of social movement research, this means we position ourselves as doing research rather

${ }^{2}$ I use the concept of belonging mainly as elaborated by Carrillo Rowe (2005) and Wright (2015) as "being and longing, as subjects and their belongings desire to connect and reconnect differently" (Wright, 2015: 399), as a way of thinking of subjectivities and power relations as relational. 
than on movements (Casas-Cortés et al., 2008; Escobar, 2008), which in practice translated into distinct ways of positioning ourselves, as we will discuss further. At the same time, we acknowledge that claims to "blur the boundaries" from the standpoint of academia are themselves infused with power. We assert with Chesters (2012: 155) that "the academy has no a priori reason or justification for making demands upon those it seeks knowledge of". Therefore, we see devoting time and energy to a wide range of movement activities not necessarily related to our research, and continuing our engagement with the movements after the research itself has ended as essential to an ethical praxis that nevertheless cannot fully resolve the tensions between academic and activist priorities. While collaboration and participation can be important elements of critical feminist research, we also recognise the limitations of these, considering that in the end, the researcher often maintains final authority over meaningmaking and representation (Preissle \& Han, 2012). Thus, we seek to align ourselves actively with social movement struggles and their prefigurative politics as they reimagine social, political and economic systems (Dinerstein, 2016; Maeckelbergh, 2016).

Another question that animates us as feminist researchers revolves around who should be the subjects of our research or perhaps rather, with whom do we choose to align ourselves? For Tamara and Daniela, departing from women's experiences (Harding, 1987) formed a key part of their research methodology. They adopted a research practice that pays attention to the effects of power on women's understandings, emotions and lived experiences of resistance, finding in those understandings, emotions and experiences "a legitimate form of knowledge that can lead to new practices and create possibilities for social change" (Harcourt, 2017: 276). While Fleur similarly prioritised an "activist standpoint" (Maddison \& Shaw, 2012) and approached the movement as cultivating knowledges and ways of being that are inherently valuable (Casas-Cortés et al., 2008; Icaza \& Vazquez, 2013), it included people of multiple genders. The three of us acknowledge that the subjects of feminist research are not limited to "women" and their experiences, as is sometimes considered central to feminist research (Raghuram et al., 1998; Taylor, 1998). Instead, we are concerned with bringing "subjugated knowledges" (Foucault, 1994) that challenge the dominant heteropatriarchal-colonial-capitalist system to the centre of analysis.

In addition, reflexivity forms an important part of our feminist research practice, as we seek to acknowledge our own role in the co-elaboration 
of knowledge with social movements, "not as an invisible, anonymous voice of authority, but as a real, historical individual[s] with concrete, specific desires and interests" (Harding, 1987: 9). This requires a constant acknowledgement that we write from our partial, rooted, subjective and embodied epistemological gazes, shaped by our positionalities, experiences and political and ethical commitments. Instead of hiding our partialities, anxieties, discomforts and contradictions, we actively embrace them and "stay with the trouble" (Haraway, 2016) as a way of deepening our understandings. For all of us, this meant that we were keeping a research journal to reflect on our own experience specifically directed at the aim of practising reflexivity. As we were building new relations and moving through the research, our own understandings and subjectivities also shifted. This demonstrates how feminist research can be understood through the metaphor of the traveller, as a journey that changes the researcher in the process (Kvale \& Brinkmann, 2009).

This reflexivity extends to the process of analysis and writing up of the research, making space for diversity and tensions, resisting the notion of writing an objective reality (Raghuram et al., 1998; Tsing, 2005). In order to do so we also became a part of a collective feminist writing group in which multiple women gathered, not only to discuss our research but how that research made us feel, the conflicts we experienced and how our positionalities affected the research and were affected by it. By doing this and writing ourselves into the research, we open up space for our emotions and learning processes. We do this as a way to make clear the situatedness and relational nature of knowledge cultivation, and to attend to the embodied knowledges and the affects that informed our research with social movements.

\section{Relating to Social Movements AS FEMINIST RESEARCHERS}

In this section, we reflect on how each of us grappled with the tensions we encountered when building relationships as feminist academic activists with social movements. The relations of power between us as researchers and the subjects of our research is an important question in feminist research (Rose, 1997). Feminist researchers have emphasised the importance of "non-hierarchical interactions, understanding, and mutual learning" (Sultana, 2007: 375), yet unequal power relations will always persist within the context of academia. Negotiating these 
power relations was a recurring struggle in our research. Our positionalities, especially as outsiders/insiders, affected how we interacted with the movements and activists, and how those shifted during the research (AduAmpong \& Adams, 2020). We see our positionality as never fully as an insider/outsider, but always partial and shifting (Dwyer \& Buckle, 2009). Our positionalities and subjectivities (Whitson, 2017) matter because they not only affect the access we have to the movements and the relationships with the people participating in our research, but also the questions we ask and the meaning we make out of our encounters (Berger, 2015).

In thinking through the power relations that structure our research, we are inspired by approaches that propose strategies for decolonising social science methodologies and research practices with social movements, and those that advocate for constructing collaborative research practices (Escobar, 2008; Espinosa, 2014; Icaza, 2018; Leyva \& Speed, 2008; Ziai et al., 2020). An important element of this is questioning what counts as valid knowledge and who has the power to know. We understand social movements as important spaces of knowledge generation rather than just objects of knowledge for social movement scholars (Chesters, 2012; Escobar, 2008). In their movements, activists are building the ways of knowing and being needed to transform the colonial, heteropatriarchal capitalist system.

At the same time, we recognise that movements in themselves are fractured, contested spaces that participate in the politics of knowledge (Flórez, 2014; Motta, 2016). One of our main concerns was with whom it would be responsible to align ourselves given the confines of MA research-time constraints, the individuality of the exercise, lack of resources, the need to produce a thesis. Being part of the dominant racial groups in each of our contexts, we particularly felt we lacked the relations to responsibly carry out research "across the colonial divide" (Escobar, 2016). One of the consequences of choosing to depart from where we are situated and trying to avoid the reproduction of colonial knowledge practices is that our research centred on communities that were similarly located (mostly) within the dominant racial groups (although also traversed by other relations of power). At the same time, we are conscious about the possible silencing effects this may have created (particularly due to the logic of academia within which we operate). 


\section{Tamara: Embroidering Feminist Activist Research with Women of the $M A B$}

My research process was built through a series of encounters with activists of the MAB, initially virtual and subsequently on-site. First, I engaged with activists of the movement's national collective of women in online conversations to introduce myself, share my interest in the movement and discuss the possibilities of doing my research with them. These initial dialogues enabled me to begin to get to know the movement and to hear from the activists what they thought was interesting and important to "be researched" and why, as well as where to geographically ground my research. I thought it was fundamental to consider not only the movement's interest but also to take into account who I am and where I come from (white woman from south Brazil, studying in Europe) and the time constraints of my MA research. Progressively, the movement opened paths for me to get closer to its complex, multi-scale struggle. Together, we decided to situate my research in the region affected by the Baixo Iguaçu dam, in south Brazil.

The way I approached the $\mathrm{MAB}$, trying to build a collaborative research practice, was inspired by decolonial research with social movements (Escobar, 2008; Lozano, 2016). One relevant aspect of such an approach was the valuation of the arpilleras as a valid source of knowledge. As Fleur reflects later on, centring marginalised knowledges is a concern of critical feminist research. Another aspect was the effort I made in my engagement with the movement's activists to create possibilities of thinking together, positioning myself as someone that was there to learn with them and trying to let the conversations flow naturally rather than making interviews or asking a predefined list of closed questions. Also, I constantly shared my own reflections and interpretations and invited the research participants to openly discuss them with me. This was especially possible to practise with those activists that hosted me during my visit to the region affected by a dam in Paraná, south Brazil, with whom I shared more time during meals, car rides and evening chimarrã $0^{3}$ circles. Thinking with others (Escobar, 2018:9) as a research practice is a process of breaking the hierarchy between researcher/researched and the dualist notion of knower/known, subject/object and academic/activist.

\footnotetext{
${ }^{3}$ Traditional South-American infused drink of yerba mate leaves.
} 
I faced multiple limitations when undertaking collaborative research with the MAB. One of them was marked by my position as an outsider, characterised by my urban background and the fact that the activists did not know me, that I was not part of the movement or of any of the movements that integrate networks with the MAB or that identify as part of the organised working-class. Also, that I am not a woman affected by a dam or have experienced socio-environmental conflicts, that even though I am Brazilian I was coming from an academic institution in the global North, among others. Being an outsider required a lot of effort to build trust and to demonstrate that I was a supporter of the movement and was politically aligned with the activists. I believe that my political position, my own fascination with the movement and my indignation in face of the injustices that people affected by the dam were suffering shined through, evidencing my alignment with the struggle. Also, much like Daniela, the fact that I had mutual friends with some of the activists helped in building trust.

Being guided by a movement I was an outsider to also meant acknowledging that I only saw snapshots of the struggle and could only access the spaces that the movement opened for me, gaining a partial and limited view. There were also benefits of being an outsider when doing research with a social movement. I perceived that people were more open to share their thoughts and experiences with me because I was not part of the movement, thus sharing critical opinions about it was not conflictive, for instance. My positionality slightly shifted during the research process, especially in relation to the activists that were hosting me, given that as days passed more trust was built between us and the spaces they opened for me widened; even invites to join the movement arose. The way I relate with the movement continues to shift given that after finishing the research for my MA thesis and back in Brazil I continued to engage with the movement. I spent a week in another region affected by a dam learning about the local resistance, participated in a regional planning meeting, took part in popular education online encounters, engaged in their digital campaigns and began to work for a local association that collaborates with the MAB in a region affected by a mining dam.

A relevant challenge of relating with a social movement as a feminist researcher was to unpack my positionality and to deal with contradictions that emerge (Harcourt \& Nelson, 2015). The place from where I embarked on this research practice is marked by my political commitments as a feminist and as a supporter of the $\mathrm{MAB}$ and the struggles 
embodied by women in the movement, but also by my entanglement with power relations. Constantly reflecting on my privileges as an educated, white, middle-class woman in a country so deeply marked by structural racism and social inequalities, and particularly through a dialogue about it with Fleur, I realised how implicated I am in the energy model that the movement is fighting and that causes harm and suffering to people affected by dams, given my socioeconomic privilege, urban way of living and my patterns of consumption. As a woman affected by a dam said to me: "people that live in cities can't see that for them to have their electricity, a lot of violence against peasants and riverine populations and against nature occur".

From this at times uncomfortable position, I constantly tried to maintain my ethical commitments through being reflexive (Sultana, 2007). I was especially concerned about the danger of romanticising women's experiences and appropriating their knowledges, and aware of the privilege of being the one who decides how the story is told, which translates into an ethical responsibility. One way of dealing with this responsibility from a feminist's perspective was to never claim to "see" from their position (Haraway, 1988: 584), making the situated place from where I was researching and writing visible (Sultana, 2007).

Also, in terms of the ethics of building relations with a social movement as a researcher, $\mathrm{I}$ assumed a posture of openness and made an effort to practise an active and sensitive listening in every dialogue, allowing closeness and emotional involvement, which was an exercise of attending to what is present but not enunciated and to relate and write from a place of affection. Part of this ethics was my conscious decision of using the terms fieldwork and field very carefully, because of the extractive rationality of these terms, grounded on the notion that the researcher goes to the field, collects raw material and then back at the academic setting produces knowledge (Barbosa da Costa et al., 2015: 270, 279). As my research process involved dealing with people's daily lives and embodied experiences, I opted for terms such as journey and encounters, keeping in mind that words matter and that choosing words has political implications.

\section{Daniela: Self-Care as a Pleasurable Form of Resistance}

Like Tamara and Fleur, I think that as researchers, our way of relating to movements sometimes arises from personal interests and politics. The way we see the world, the issues that "pass through our bodies", the struggles 
that represent us can facilitate our approach to social movements, and that is precisely how my approach came into being. In the past, I built relationships with other feminists in my city and created links with women who are at the forefront of abortion rights activism groups. I observed and heard about the self-care dynamics they have and those I felt were missing, and as a psychologist, I questioned the repercussions of these dynamics.

In conversations prior to my research, I heard the demand of some activists to find a way to work on self-care and burnout (even when human and time resources were lacking) and I saw an opportunity to contribute to the movement from my position. My first concern was how to contribute to a movement I was an outsider to and being in another country I felt that I could not contribute as I wished to. For a while I only valued the activism that took me to the streets, but I realised later that by questioning the value of the type of activism I could do, I was not doing any of it. Due to this, I decided to start by incorporating it into what I was doing at the moment, which was research for my MA.

In terms of positionality, I believe that my particular situation made it easier for me to approach the topic of self-care with the activists. I was an outsider to the movement, therefore it was simpler to discuss the internal dynamics that caused conflict within it and affected their mental health. As Tamara, I was not part of any group or perceived as loyal to anyone specific and that allowed everyone to feel more comfortable during the interviews. We were then able to discuss internal conflicts that have an impact on their self-care and the history of the movement that sometimes adds to those conflicts and hinders the efforts to communicate assertively with other activists. At the same time, though, I am a young, feminist, Costa Rican woman who has shared spaces with a lot of these women, such as protests, human rights events and discussion groups. Some of them know me or of me through mutual friends and because of that, they felt comfortable and keen to help me with my research. That was also my entry point into the movement when I started my research, as I was in contact with different actors inside the movement and was able to create a call out for interviews that reached the different groups involved.

Part of doing feminist research, though, was acknowledging that choosing this topic was my desire, and not a demand from the activists. I believed that the issue of self-care was interesting and that I could contribute in some way to improving their conditions, but it was me coming to them to suggest a topic, and to ask for their collaboration. 
I struggled, because I recognised that I did not have enough time to take on a participatory approach, therefore I knew that I had to be reflexive and adapt myself, and the methodologies, to the possibilities of the participants and not the other way around. Especially when discussing care, my focus was to be caring in my interactions with the activists. I initially wanted to conduct focus groups, to not only talk about individual selfcare, but collective care. I wanted to facilitate self-care workshops to provide a space they were struggling to create for themselves and, in my mind, to contribute in some way during my research. Nonetheless, this proved difficult for them for several reasons (such as time and internal conflicts) and I found myself reflecting if this was an actual demand or a reflection of my own perception of their needs.

The participants' time constraints and concerns with the group methodologies were a limitation throughout the research, but also a reflective practice that allowed me to adapt to, and prioritise the possibilities of the participants, as well as remain critical to my own ideas and practices. After several adjustments, I decided to have individual interviews and within those conversations I received more input as to why the group methodologies did not work for this specific research. I got an inside look into the movement and realised that some of the dynamics that were creating pressure for the activists were related to the relationships between them and their communication. Infighting as an obstacle for care was eventually one of the findings of my research and an additional reason to uphold individual experiences and not only the commonalities between them.

Furthermore, I made efforts to nurture my bonds with the activists and to stray from the idea of "objectivity" using my feelings and thoughts as material that informed those relations, instead of tarnishing them. This was something the three of us did (in different ways) that resulted in enriching discussions and the formation of bonds that went beyond that of researcher and participants. Eventually, after the research was done I continued to have conversations with the activists and was contacted to facilitate self-care workshops for some of the groups, which confirmed to me how much more fruitful conversations can be when started by the communities and not the other way around.

Finally, as a psychologist I could not ignore the fact that mental health was always a concern for me when getting involved in activism and a topic that kept recurring every time I had discussions with friends that were more involved than me. It was a priority and it is part of my positionality 
as a researcher that I considered it an important issue to explore. It was also key for me, as a psychologist, to have that self-care that I sought to underline through my research. In an academic context where objectivity is highly valued and being professional is often related to being "emotionless", talking about my research, how it made me feel and the limitations I had was vital for me to oppose this traditional view. As in my psychological practice, I realised that having regular meetings with colleagues gave me ideas, knowledge and feedback to make sure that my research was first and foremost, respectful. As well as creative and fun. Not only for the participants but for myself as well. One of the participants from the research I conducted mentioned that part of self-care is making sure to remember that there is no resistance without pleasure, and I believe part of doing feminist research is embodying that belief in your process as well.

\section{Fleur: Blurring the Boundaries Through Activist Research}

Like Daniela and Tamara, my research also evolved out of my previous experiences and interests, in my case with the Dutch climate movement. I had been involved with green youth politics for several years and had been questioning some of the exclusions I experienced. In addition, my concerns and fears of climate change and hope for a more just world meant that I was looking to get more involved in climate justice activism. I wanted to conduct research within The Netherlands, as it was important for me to be aware of where I was situated, and more closely examine the possibilities of systemic change within the Global North. Nevertheless, I was relatively new to the climate justice movement, to Extinction Rebellion and to activism in general, thus making me a relative "outsider". Still, I had the advantage of doing research within the city and country that I was living in at the time, which provided me with more time and opportunities to form deep relationships. Additionally, the movement I was researching was only just emerging, which allowed me to quickly establish relations with many organisers and contribute to the process of building the movement from the ground up, while Tamara and Daniela had to weave their way through movements that had been active for a long time, with many of the relations already established.

From an early stage, I was concerned with the issue of whom and for what we, as social scientific researchers, are producing knowledge (Leyva \& Speed, 2008: 47). I hoped to identify research questions that 
would be useful to XR, by collaborating with other activists to shape my research. I considered a participatory approach, in which the researcher works together with the "participants" to answer these questions the "ideal" way of mitigating power relations. However, I struggled to implement this. I attributed some of these difficulties to constraints inherent to academic research, including limited time and resources (Leyva \& Speed, 2008) and the fact that activism has its own temporality. In hindsight however, I am also able to appreciate how my positionality determined what questions were possible to ask. From my "outsider" position, I did not have access to the questions relevant to other movement actors due to my limited relation to them. It is through organising and resisting together with the movement for a longer period of time that I have developed an understanding of the questions that are relevant to ask. I also experienced my researcher positionality as a barrier to collective knowledge creation as I felt that the need to write a thesis meant there was always an "ulterior motive".

I was also committed to feminist concerns to centre marginalised or subjugated knowledges in my research. Within the context of the climate movement, I interpreted this as the need to centre non-white, nonuniversity educated and working-class voices, as I was concerned with absences along the lines of race and class. This made me hesitant to focus my research on XRNL, which I perceive as hegemonically situated in the context of the climate movement. Through conversations with Tamara about the ways in which we are implicated in the oppressions we were trying to address (related to the energy model in Brazil and "whitestream" environmentalism in The Netherlands, respectively) I was able to appreciate the importance of departing from where I am situated. As I was myself departing from a dominant position within the climate movement being white and university educated, I did not want to pretend I could speak to the perspectives of people marginalised or ignored by the movement better than they could speak for themselves (hooks, 1990: 241-243). I have however come to understand my positionality not just in terms of a politics of location (Rich, 1984), but also as a politics of relation (Carrillo Rowe, 2005) that formed the point of departure for my research analysis. It was not necessarily my social location that limited my research in terms of what I considered to be ethical, but the fact that I lacked the relations to meaningfully engage across difference-and that it would not be possible to build these relations within the time constraints of my MA research. 
Zavos and Biglia (2009) highlight how activist research is distinct from ethnography because the object of study is partially shaped by the researcher/activist's presence. Within XRNL, I ended up participating intensively in the process of knowledge and subjectivity formation, subverting the subject-object divide in research. My positionality and subjectivity shifted considerably during the research, affecting the way in which I made sense of the "data". For instance, being involved in XR made me increasingly relate to the climate and ecological crisis through emotions. This led me to unpack how I had internalised dominant rational, scientific approaches in relation to climate change and caused me to shift my understanding of the way XR relates to these subjectivities. Noting down my own emotions, tensions and changing perspectives during the research through journaling became an important part of my research practice. My research methodology became an embodiment of the resistance of dominant knowledges and subjectivities by giving primacy to subjugated knowledges that emanate from experience and emotions.

My intimate researcher positionality also created new ethical and practical dilemmas (Preissle \& Han, 2012). There often existed ambiguity around my role as a researcher vs. activist. As opposed to Tamara and Daniela, I was less concerned with building trust, and more with the responsibility placed into my hands as a researcher by the trust that emanated from "being a fellow rebel", that I would not harm the movement and make the right ethical choices. It would have been useful to set up certain boundaries around my researcher and activist identity following Biglia's adoption of a "complex borderline position" (Zavos \& Biglia, 2009), for instance by deciding that not all of my activist work needed to inform the research, and bounding research practices to more formal events like interviews or specific conversations. Eventually, most of my research did come to rely on interviews as a result of my own negotiation of ethical and practical concerns. This illustrates that while in some cases, feminist methodologies may lead us to reject the interview as a method that does not allow for co-creation of knowledge (as in Tamara's case), in others it may lead us to see interviews as essential to maintaining some of the boundary-work between activism and research that may be ethically necessary after all. 


\section{How Can Feminist Activist Research Contribute to Social Movement Struggles?}

Throughout the research process, all of us were concerned about the question of who and for what we are producing knowledge. We engaged in continued reflection about the relationships between academia and activism, and the contributions that we could make towards social change. We wondered if what we were bringing to the table was enough, if it was helpful, and if it was relevant and politically useful for the social movements we were working with (Leinius, 2020). By discussing these questions with each other, we realised that we had a common understanding that our research carried "the potential for transformative dialogue" (Chatterton et al., 2007: 219) that is in itself a way of contributing to social change.

\section{Tamara: Connecting Academic Feminist Research with the Movement's Popular Education Feminist Methodology}

Several activists of the Movement of People Affected by Dams shared with me that they were quite used to being contacted by academics interested in the movement, and I constantly feared being another extractive researcher: one that goes to "the field" with closed and defined ideas, collects information and goes back to academia to "produce knowledge", never returning again (Barbosa da Costa et al., 2015; Leyva, 2015). My way of negotiating this risk involved letting the movement guide me, being open to what they wanted to show me and sometimes accepting to let go of my interests and priorities, questioning them on how academic feminist research could be useful for them and contribute to their struggle. Instead of a relation of extraction, I aimed to engage in a horizontal relationship, interacting, discussing, reflecting and collaborating, bringing different knowledges together (Lozano, 2016: 20; Motta, 2011: 196). I certainly faced several limitations and had to deal with the frustration of realising that it was really hard to put most of these ideas into practice, especially considering that I had very limited time for research, that the writing process took place geographically far away from the movement, that I was writing in English and not in Portuguese, and that in the end I was the one with the final authority over the research and its results (Leinius, 2020: 74). 
Furthermore, I had to deal with the fact that not all the activists were interested or thought it was relevant to discuss how academic research could be useful to the movement. Some of them showed excitement and openness in talking to me about their experiences of struggle, but not necessarily interest in discussing what I was going to write based on those conversations, while others were keen to know more about my theoretical framework, for instance. Asking the activists how academic research could be useful for them also involved receiving sincere (and sometimes ironic) answers, such as invitations for me to join the movement, implying that I would contribute more by moving to the territory affected by the dam and building the resistance on the ground with them.

An important aspect of my experience of mobilising a feminist methodological approach to come close to the MAB that I want to reflect on is related to the arpilleras, my guides in this process. Metaphorically, my research was guided by the arpilleras, through which the stories of women affected by dams resisting in different parts of Brazil initially reached me. Approaching women affected by dams through their embroideries was also a process of collectively giving value to alternative forms of knowledge and tools of resistance. The arpillera is a form of knowledge and a tool that is frequently diminished because it is not considered really political, especially by men who see arpilleras as something secondary that women do. I share with Daniela the conviction that the valuation of what is frequently side-lined in political practice or not considered political—self-care and art-is extremely relevant. Bringing artistic expressions of women affected by dams to the centre with the activists that have been claiming its meaning as a political tool was an important choice of my practice of relating with the movement and contributing as a researcher-activist.

With their art-based resistance, women in the MAB have been constructing their own "popular education feminist methodology" (MAB, 2015) -in which arpilleras work as a tool for creating spaces for women to debate about power relations within the movement and to reflect on and translate their experiences of struggle and resistance, enunciating what has systematically been silenced, both individually and collectively, through the act of embroidering. The feminist activist research practice I aimed to build relates with the popular education feminist methodology of arpilleras in the sense that it materialises through encounters, collaborative work, moments of listening and sharing emotions and letting stories come together and blend into one another. 
Bringing arpilleras to the centre speaks about listening to women's voices and reaffirming with them the political meaning of arpilleras as counterhegemonic purposes that rise up to contest dominant narratives of the energy development model in Brazil.

\section{Daniela: Self-Care as a Dialogue for Transformation}

One of the concerns that kept me reflective during the research was the importance of focusing on the activists' stories and experiences. I believed in the power of highlighting their voices and the way they wanted to be portrayed, and I later on reflected on the relation that this had with the focus of my research. I consider their efforts to focus on the social burdens and benefits of care, and using them as a way to contribute to social change, as remarkable. In an attempt to mirror this in my research I focused on the burdens that affect them as activists, and the lack of information about their experiences. Bringing the topic of self-care to the centre of a conversation that is often focused on the outcomes of the movement and its methodologies, and not the activists themselves, became an attempt to reflect their beliefs around care and their effort to bring it to the forefront of their activism, as a counter-hegemonic practice.

Initially, I had specific intentions with my research, I believed that the only way to contribute was to act based on the information I received. I thought I had to contribute with practical tools regarding self-care and had thought of conducting workshops with those interested, but I had to come to terms with the fact that at the moment, this would have only added to the workload these women had. As one of them told me: "You have to be careful not to turn your self-care into another task on your to-do list".

During the process, similarly to Fleur, I realised that another way of striving for social change was to contribute to ongoing conversations of resistance and to the development of critiques that are used to empower and inform the movement (Chatterton et al., 2007: 219). The research we created motivated reflection about their mental health and the weight that the work has on these women. As well as how the dynamics of power within the movement affect their efforts to achieve social change. "[C]hange, therefore, is about movement in which the journey is more important than a hoped-for utopia" (Chatterton et al., 2007: 221) and I would add, change is about focusing on the possible dialogues for transformation and how they could take us one step closer to that utopia. 


\section{Fleur: Building and Sustaining Relations as Social Change}

I departed from the hope that my research would contribute to addressing some of the silences and exclusions in XRNL that reinforce dominant understandings of climate change as a technical-environmental problem and centre whiteness and masculinity. I was guided by Casas-Cortés et al. (2008) approach to social movement research of translation and description of movement knowledges, but I continuously wondered how this was useful to the movement, considering its members already had a deep understanding of these knowledges. Thus, I shared Tamara's fear of exacerbating the extractive dynamic of the research practice (Leyva \& Speed, 2008). I was also relatively inexperienced in both activism and academia, meaning that I had limited understanding of different research tools that could support a feminist methodology, as well as limited skills to facilitate knowledge co-creation. Observing how their graduate students encountered similar problems, Maddison and Shaw (2012) suggest that feminists may need to reconceptualise the meaning of activism in research. Perhaps there are other ways of conducting feminist research that do not necessarily emphasise participation, but are able to leverage better what graduate research has to offer social movements, while limiting the demands of time and energy that the researcher makes on others. I think that the most important contribution of graduate research can be simply having the time and space to engage in-depth with certain topics, which is a scarce resource in action-oriented movements. This can be leveraged in many ways, including conducting interviews to make activist stories more accessible (Zavos \& Biglia, 2009), or using discourse analysis to better understand the narratives of the movement (Moss, 2009).

This led me to reconceptualise co-creation of knowledge. As Daniela also suggested, I came to understand that I was engaging in collaborative knowledge cultivation through continuous involvement in movement conversations. Perhaps it does not make sense to think of research and activism as separate, but as Maxey (1999) suggests seeing research as another possible way of practising activism, recognising research and social movement praxis as complementary practices aimed at making sense of the world, creating meaning, knowledge and building relations. Thought this way, the contributions that I was able to make emerge more clearly. I established many invaluable relations: this includes the building of a working group and community of practice to address issues of power 
and oppression within XRNL, as well as an ongoing relation with decolonial and Indigenous climate justice activists that I initiated in the context of my research. In addition, the combination of both using and questioning the discourses and practices of XRNL as an activist researcher opened up important spaces for reflection and new questions to ask (Zavos \& Biglia, 2009). I concur with Zavos' (Zavos \& Biglia, 2009) observation that it is important to offer my insights as one, but not the only possible interpretation of activist practices and narratives, which has thankfully resonated with many of the people in XRNL with whom I have shared my research.

\section{Final Thoughts}

All three of us have been guided by a commitment to make the social movements we have been working with not merely the objects of our investigation, but to build a collaborative approach that prioritises the questions that are relevant to ask for the movement, building long-term relationships and offering up our insights to support and strengthen the movements. This however demands deep involvement, which is very hard to achieve within the limited scope and time of a MA thesis process (Trzeciak, 2020). We felt that the restrictions imposed on graduate research conflicted with what we perceive to be important for feminist research: participatory, collaborative, action-oriented, reciprocal and relational rather than extractive, contributing to transformative change. This led us to frequently question the value of doing research within this framework, and in what way it is complementary to or, as put by Leyva (2015), in tension with political activism. Together with our co-feminist researchers we often lamented what we perceived as the insignificance of our research, questioning the relevance of the many hours spent behind the screen while the activists we worked with were busy organising.

Although we were inspired by feminist research approaches seeking to collapse the divide between academia and activism (Casas-Cortés et al., 2008), we have come to feel that this is neither always possible nor always desirable. We do find the idea of moving between these terrains as complementary (and sometimes conflicting) ways of making sense of the world (Moss, 2009) or perceiving research as possibly residing within the sphere of activism more useful (Maxey, 1999). Rethinking the academiaactivism dichotomy (Leyva, 2015) can help us redefine what academia is, what activism is, and challenge a hierarchy of what counts as "real" 
activism and as "valid" knowledge. Importantly though, our experiences of researching with social movements using feminist methodologies went way beyond writing and submitting an academic piece, in different but related ways. It translated into a continuous involvement through which the spaces for dialoguing and building knowledge and relations multiply. The activist-academic learning and the relations built through the research were probably its most important "outcomes". As our insider/outsider positionality shifted, it also opened up new perspectives and new questions to ask.

Finally, and as reflected upon earlier, part of the practice of feminist research for us existed in the collective effort and creation of spaces for colearning and reflecting with fellow researchers. Throughout the process, we regularly convened with friends and colleagues to provide muchneeded emotional support, critical feedback and thinking through each other's problems. In this way, we were exploring ways of doing research relationally and co-creatively, not just between researchers and participants, but also between researchers working on different projects, giving shape to our feminist research practice and informing our friendships.

\section{REFERENCES}

Adu-Ampong, E. A., \& Adams, E. A. (2020). "But you are also Ghanaian, you should know": Negotiating the insider-outsider research positionality in the fieldwork encounter. Qualitative Inquiry, 26(6), 583-592.

Barbosa da Costa, L., Icaza, R., \& Talero, A. O. (2015). Knowledge about, knowledge with: Dilemmas of researching lives, nature and genders otherwise. In W. Harcourt \& I. L. Nelson (Eds.), Practising feminist political ecologies: Moving beyond the 'green economy' (pp. 157-181). Zed Books Ltd.

Berger, R. (2015). Now I see it, now I don't: Researcher's position and reflexivity in qualitative research. Qualitative Research, 15(2), 219-234.

Carrillo Rowe, A. (2005). Be longing: Toward a feminist politics of relation. NWSA Journal, 17(2), 15-46.

Casas-Cortés, M. I., Osterweil, M., \& Powell, D. E. (2008). Blurring boundaries: Recognising knowledge-practices in the study of social movements. Anthropological Quarterly, 81(1), 17-58.

Chatterton, P., Fuller, D., \& Routledge, P. (2007). Relating action to activismTheoretical and methodological reflection. In S. Kindon, R. Pain, R \& M. Kesby (Eds.), Participatory action research approaches and methods: Connecting people, participation and place. Routledge. 
Chesters, G. (2012). Social movements and the ethics of knowledge production. Social Movement Studies, 11(2), 145-160.

Crenshaw, K. (1989). Demarginalising the intersection of race and sex: A black feminist critique of antidiscrimination doctrine, feminist theory and antiracist politics. University of Chicago Legal Forum, 1(8), 139-167.

Dinerstein, A. C. (2016). The radical subject and its critical theory: An introduction. In A. C. Dinerstein (Ed.), Social sciences for an other politics: Women theorising without parachutes (pp. 1-15). Palgrave Macmillan.

Dwyer, S. C., \& Buckle, J. L. (2009). The space between: On being an insideroutsider in qualitative research. International Journal of Qualitative Methods, $8(1), 54-63$.

Escobar, A. (2008). Territories of difference: Place, movements, life, redes. Duke University Press.

Escobar, A. (2016). Thinking-feeling with the earth: Territorial struggles and the ontological dimension of the epistemologies of the South. Revista de Antropología Iberoamericana, 11(1), 11-32.

Escobar, A. (2018). Prologo. In X. Leyva, J. Alonso, R. Hernández, A. Escobar, A. Köhler, A. Cumes, \& W. Mignolo (Eds.), Prácticas otras de conocimiento(s): Entre crisis, entre guerras (Tomo I) (pp. 9-11). Cooperativa Editorial RETOS, Taller Editorial La Casa del Mago, CLACSO.

Espinosa, Y. (2014). Etnocentrismo y colonialidad en los feminismos latinoamericanos: Complicidades y consolidacion de las hegemonias feministas en el espacio transnacional. In Y. Espinosa, D. G. Correal, \& K. O. Muñoz (Eds.), Tejiendo de otro modo: Feminismo, epistemología y apuestas descoloniales en Abya Yala (pp. 309-234). Editorial Universidad del Cauca.

Flores, D. (2019). How do they cope? Self-care lessons from abortion rights activists in Costa Rica. MA Thesis, International Institute of Social Studies, The Hague.

Flórez, J. F. (2014). Lecturas emergentes: Volumen II: Subjetividad, poder y deseo en los movimientos sociales. Editorial Pontificia Universidad Javeriana.

Foucault, M. (1994). Two lectures. In S. Dirks, N. Eley, \& G. Ortner (Eds.), Culture, power, history (pp. 200-221). Princeton University Press.

Harcourt, W. (2017). Glocal networking for gender equality and sustainable livelihoods. In S. Shortall \& B. Bock (Eds.), Gender and rural globalization: International perspectives on gender and rural development (pp. 272-287). CABI.

Harcourt, W., \& Nelson, I. L. (Eds.). (2015). Practising feminist political ecologies: Moving beyond the "green economy." Zed Books Ltd.

Harding, S. (1987). Introduction: Is there a feminist method? In S. Harding (Ed.), Feminism and methodology: Social science issues (pp. 1-14). Indiana University Press. 
Haraway, D. (1988). Situated knowledges: The science question in feminism and the privilege of partial perspective. Feminist Studies, 14(3), 575-599.

Haraway, D. (2016). Staying with the Trouble: Making Kin in the Chthulucene. Duke University Press.

hooks, b. (1990). Marginality as resistance. In R. Ferguson, M. Gever, T. T. Minh-ha \& C. West (Eds.), Out there: Marginalisation and contemporary cultures (pp. 241-243). MIT Press.

Icaza, R. (2018). Social struggles and the coloniality of gender. In O. U. Rutazibwa \& R. Shilliam (Eds.), Routledge handbook of postcolonial politics (pp. 58-71). Routledge.

Icaza, R., \& Vazquez, R. (2013). Social struggles as epistemic struggles. Development and Change, 44(3), 683-704.

Kvale, S., \& Brinkmann, S. (2009). Interviews: Learning the craft of qualitative research interviewing. Sage.

Leinius, J. (2020). Postcolonial feminist ethics and the politics of research collaborations across north-south divides. In A. Ziai, D. Bendix, \& F. Müller (Eds.), Beyond the master's tools?: Decolonizing knowledge orders, research methods and teaching (pp. 71-91). Rowman \& Littlefield.

Leyva, X. (2015). ¿Academia versus activismo? Repensarnos desde y para la práctica teórico-política. In X. Leyva, C. Pascal, A. Köhler, H. Olguín Reza, \& M. R. Velasco Contreras (Eds.), Prácticas otras de conocimiento(s): Entre crisis, entre guerras (Tomo II) (pp. 199-222). Cooperativa Editorial Retos.

Leyva, X., \& Speed, S. (2008). Hacia La Investigación Descolonizada: Nuestra Experiencia de Co-labor. In X. Leyva, A. Burguete, \& S. Speed (Eds.), Gobernar (en) la Diversidad: Experiencias Indigenas Desde América Latina. Hacia la Investigación de Co-labor (pp. 34-59). CIESAS, FLACSO Ecuador and FLACSO Guatemala.

Lozano, R. B. (2016). Tejiendo con retazos de memorias insurgencias epistémicas de mujeres negras/afrocolombianas. Aportes a un feminismo negro decolonial. Unpublished Ph.D. thesis. Universidad Andina Simón Bolívar Sede Ecuador.

MAB. (2015). Mulheres atingidas por barragens em luta por direitos e pela construção do projeto energético popular. Secretaria Nacional MAB.

Maddison, S., \& Shaw, F. (2012). Feminist perspectives on social movement research. In S. N. Hesse-Biber (Ed.), Handbook of feminist research: Theory and praxis (pp. 583-605). Sage.

Maeckelbergh, M. (2016). The prefigurative turn: The time and place of social movement practice. In A. C. Dinerstein (Ed.), Social sciences for an other politics: Women theorizing without parachutes (pp. 121-134). Palgrave Macmillan.

Maxey, I. (1999). Beyond boundaries? Activism, academia, reflexivity and research. Area, 31(1), 199-208. 
Moss, P. (2009). Positioning a feminist supervisor in graduate supervision. Journal of Geography in Higher Education, 33(1), 67-80.

Motta, S. (2011). Notes towards prefigurative epistemologies. In S. Motta \& A. G. Nilsen (Eds.), Social movements in the global south: Dispossession, development and resistance (pp. 178-199). Palgrave Macmillan.

Motta, S. (2016). Decolonising critique: From prophetic negation to prefigurative affirmation. In A. C. Dinerstein (Ed.), Social sciences for an other politics: Women theorising without parachutes (pp. 33-48). Palgrave Macmillan.

Motta, S., \& Esteves, A. M. (2014). Reinventing emancipation in the 21 st century: The pedagogical practices of social movements. Interface, 6(1), 1-24.

Philip, G., \& Bell, L. (2017). Thinking critically about rapport and collusion in feminist research: Relationships, contexts and ethical practice. Women's Studies International Forum, 61(1), 71-74.

Preissle, J., \& Han, Y. (2012). Feminist research ethics. In S. N. Hesse-Biber (Ed.), Handbook of feminist research: Theory and praxis (pp. 583-605). Sage.

Raghuram, P., Madge, C., \& Skelton, T. (1998). Feminist research methodologies and student projects in geography. Journal of Geography in Higher Education, 22(1), 35-48.

Rich, A. (1984). Notes towards a politics of location. In Blood, bread and poetry: Selected prose 1979-1985 (pp. 210-231). Little Brown \& Co. Rpt. in R. Lewis \& S. Mills (Eds.), (2003). Feminist postcolonial theory: A reader (pp. 29-42). Edinburg University Press.

Rose, G. (1997). Situating knowledges: Positionality, reflexivities and other tactics. Progress in Human Geography, 21(3), 305-320.

Rusansky, T. (2019). Embroidering resistance: Daily struggles of women affected by the Baixo Iguaçu Hydropower Dam in Paraná, South Brazil. MA Thesis, International Institute of Social Studies, The Hague.

Sultana, F. (2007). Reflexivity, positionality and participatory ethics: Negotiating fieldwork dilemmas in international research. ACME: An international E-journal for Critical Geographies, 6(3), 374-385.

Taylor, V. (1998). Feminist methodology in social movements research. Qualitative Sociology, 21(4), 357-379.

Trzeciak, M. F. (2020). "Tell us something about yourself, too"-Reflections on collaborative research as a tool for a reflexive methodology. In A. Ziai, D. Bendix, \& F. Müller (Eds.), Beyond the master's tools: Decolonizing knowledge orders, research methodology, and teaching (pp. 117-133). Rowman \& Littlefield.

Tsing, A. (2005). Friction: An ethnography of global connection. Princeton University Press.

Whitson, R. (2017). Painting pictures of ourselves: Researcher subjectivity in the practice of Feminist Reflexivity. The Professional Geographer, 69(2), 299-306. 
Wright, S. (2015). More-than-human, emergent belongings: A weak theory approach. Progress in Human Geography, 39(4), 391-411.

Zantvoort, F. (2019). Rebel or Sink? Belonging, relational subjectivities and the politics of knowledge in Extinction Rebellion Netherlands. MA Thesis, International Institute of Social Studies, The Hague.

Zavos, A., \& Biglia, B. (2009). Embodying feminist research: Learning from action research, political practices, diffractions, and collective knowledge. Qualitative Research in Psychology, 6(1-2), 153-172.

Ziai, A., Bendix, D., \& Müller, F. (2020). Decolonizing knowledge orders, research methodology and the academia: An introduction. In A. Ziai, D. Bendix, \& F. Müller (Eds.), Beyond the master's tools: Decolonizing knowledge orders, research methodology, and teaching (pp. 1-15). Rowman \& Littlefield.

Open Access This chapter is distributed under the terms of the Creative Commons Attribution 4.0 International License (http://creativecommons.org/ licenses/by/4.0/), which permits use, duplication, adaptation, distribution and reproduction in any medium or format, as long as you give appropriate credit to the original author(s) and the source, a link is provided to the Creative Commons license and any changes made are indicated.

The images or other third party material in this chapter are included in the work's Creative Commons license, unless indicated otherwise in the credit line; if such material is not included in the work's Creative Commons license and the respective action is not permitted by statutory regulation, users will need to obtain permission from the license holder to duplicate, adapt or reproduce the material.

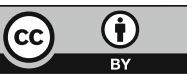

